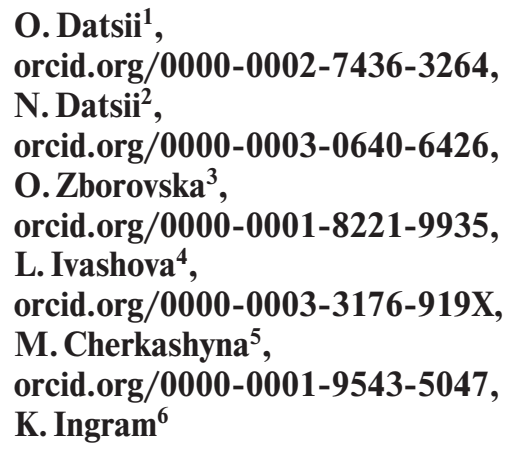

1 - Interregional Academy of Personnel Management, Kyiv, Ukraine, e-mail: rvps1973@gmail.com

2 - Polissia National University, Zhytomyr, Ukraine

3 - National University in Zaporizhzhia, Zaporizhzhia, Ukraine

4 - University of Customs and Finance, Dnipro, Ukraine

5 - National Academy of the National Guard of Ukraine, Kharkiv, Ukraine

6 - Vilniaus Kolegija, University of Applied Sciences, Vilnius,

Republic of Lithuania

\title{
FINANCING OF ENVIRONMENTAL PROGRAMS FOR INDUSTRIAL WASTE MANAGEMENT IN TIMES OF CRISIS
}

Purpose. To conduct an analysis of funding from state and regional budgets for environmental needs in general and itemized as "waste management", to identify correlations of data and to build on their basis a mathematical apparatus for forecasting the financing of environmental needs in the event of a budget crisis.

Methodology. The results of the study were obtained using general and special methods of cognition. Methods of comparative analysis, content analysis and logical generalization were used to analyze the financing of environmental needs in general as well as waste management, in particular. Methods of quantitative and qualitative comparison were used to detect data correlation and isolation from random effects on the resulting function of non-random components. Methods of scientific abstraction and mathematical formalization were used to form a mathematical apparatus for forecasting the financing of environmental needs in the event of a budget crisis.

Findings. It is proposed to introduce a strategic systems approach to address pressing issues of environmental protection and industrial waste management in the face of a shortage of financial resources both at the state level and at the regional level. The mathematical apparatus has been formed for this purpose. The increasing relevance of the forecast was achieved by introducing an original methodology. Trends and features of budget financing of ecological programs at the state and regional levels are revealed. With a chronic lack of financial resources, there is a tendency of a steady increase in current costs of waste management. Peculiarities of financing ecological needs from regional budgets are studied. It is stated that regional budgets are affected not only by the risks inherent in national funding, but also by their own sets of risks.

Originality. The presence of correlated components in white noise of ARMA-models increased the relevance of forecasts of financing environmental programs in the crisis. The practical reliability of the correlation between some components of white noise and the integrated indicator of the level of economic security is established. It was found that the financing of environmental programs from regional budgets is characterized by more uneven changes than in the case of state funding.

Practical value. Forecasts for the volume of industrial waste for disposal in specially designated places and the volume of capital investment and current costs of waste management have been developed. The possibilities of the mathematical model for the formation of forecasts of future periods are tested. Forecasts for the following years and approximations of previous periods are presented in a convenient analytical form to be used by specialists. Forecasting budget revenues for environmental needs allows planning a phased solution to environmental problems and attracting the necessary external financial resources, increases the ability of public control of financial flows and access to the planned indicators of each of the environmental investment objects. In a broader sense, it provides a tool for shaping the sphere of environmental protection as a single system.

Keywords: budget expenditures, industrial waste, modeling, forecasting, waste management

Introduction. The crisis situation with the generation, recycling and accumulation of industrial waste in Ukraine was declared at the governmental [1] and legislative levels (On Waste: Law of Ukraine (1998). No. 187/98-BP), by the public and the scientific community. According to the government document [1] adopted in 2017, specific actions and restrictions were proposed to reduce the accumulation of industrial waste at designated landfills. In particular, the use of primary raw materials had to be reduced by $30 \%$. Ukraine has also made commitments to implement European norms and rules on waste management (Directive 2008/98/EC of the European Parliament and of the Council of 19 November 2008 on waste and repealing certain Directives (2008)). Official Journal of the European Union 312, 0003-0030). But the area of landfills for waste accumulation is still increasing, including even unsorted waste mixed with the waste of I-III hazard classes [2, 3]. Changing the forms of statistical accounting [4] in Ukraine made it possible to obtain new data on the state of industrial waste management. According to these reporting forms,

(c) Datsii O., Datsii N., Zborovska O., Ivashova L., Cherkashyna M., Ingram K., 2021
419.2 million tons of industrial waste is generated annually in Ukraine. 13.27 billion tons is in the places of accumulation. But industrial waste has been accumulating in Ukraine since the beginning of the industrial revolution, and the volume of landfills of a significant number of enterprises that have closed since then is not taken into account. But even without these stocks, the state of waste management policy is threatening to both the environment and the health of the population.

Literature review. Analysis of the use of the experience of countries where the problem of waste management has been solved, opportunities and ways to adapt the experience of developed countries, new research in this area are dealt with in the works by Ukrainian scientists. An adaptive approach to the use of world experience is given in the works by Petruk [5], Melnyk [6], Voitsikhovska [7]. Golyan [8] pointed out the institutional prerequisites of investment support for the development of production in combination with waste recycling under the project approach to waste management. Technologies for industrial waste management, the formation of efficient operation of landfills for its storage require sustainable and sufficient funding. Approaches to the formation of rational financial management during the crisis, the characteristic conse- 
quence of which is the lack of financial resources, are analyzed in detail in the works by Chugunov [9], Ivanova [10]. The instability of the economy and, accordingly, budget investment into environmental projects is exacerbated in Ukraine by economic and social transformations, the institutional foundations of financial regulation of the state which are studied by Bondarenko [11]. Sokiran [12] studied the transformation of budget policy in the crisis period. The works by foreign researchers, Azzimonti [13] in particular, deal with this topic. He studied aspects of public budgeting in the context of increasing public debt and, consequently, increasing risks. Macroeconomic features presented in [13], in particular income inequality, are also characteristic of Ukraine. An approach to the analysis of financial flows, some elements of which are taken into account is also presented in [13, 14].

The purpose of the article is to analyze the financing of environmental needs in general and the budget item "waste management" from state and regional budgets, to identify data correlations and form a mathematical apparatus for forecasting the financing of environmental needs in the conditions of a budget crisis.

Methods. The results of the study were obtained using general and special methods of knowledge. Methods of comparative analysis, content analysis, logical generalization were used to analyze the financing of environmental needs in general and according to the budget item "waste management". The method of quantitative and qualitative comparison was used to identify the correlation of data and isolation from random effects on the resulting function of non-random components. Methods of scientific abstraction and mathematical formalization were used to create a mathematical apparatus for forecasting the financing of environmental needs in the conditions of a budget crisis.

Results. Research on financing of ecological needs in general and on waste management using the methods of comparative analysis, content analysis, logical generalization. The complexity of the environmental situation in the sphere of generation, recycling and accumulation of industrial waste leads to the intensification of state institutions and regional authorities in this area. There is, despite the unevenness of this process, a tendency to increase funding for environmental activities. But the financial instruments involved do not lead to strategic changes in the sphere of environmental protection and reduction of the load on waste storage facilities. The reason for this, in our opinion, is the following: for the existence of an appropriate regulatory framework, there is a lack of system in the implementation of long-term environmental plans; lack of necessary financial resources from central and local authorities for the implementation of strategic environmental projects; control over the use of allocated financial resources is not effective; insufficient development of public environmental awareness, which causes an insufficient level of public control over the effective spending of money to solve the problem of industrial waste management.

According to budget reports, national capital investments in environmental protection for all types of environmental measures in 2019 amounted to $\$ 580.4$ million. Of these, $\$ 205.4$ million, i. e. $35.3 \%$ of the total, was invested in waste management. As the analysis shows, capital investments do not come in evenly from year to year and their distribution by types of environmental measures is also extremely uneven. This is evidence of the difficulties in shaping the strategic policy of environmental budgeting and limitation of financial resources. The funds, as shown by the analysis of statistical information [4], are mainly allocated through the operational financing of the most pressing needs of environmental protection. The analysis of financing of environmental programs from municipal, local and regional budgets indicated some differences from similar budgeting from the state budget. According to the budgets of the regions, capital investments in environmental protection are even more uneven from year to year than at the state level (Fig. 1) [4]. Despite a certain increase in capital investment in 2019 compared to previous years, in some regions, such as Dnipropetrovsk region, where the main industrial production is concentrated, and this, in turn, increases waste in these regions, there is even a reduction in capital investment for waste treatment (2019 to 2018). The summary data of capital investments in environmental protection according to regional budgets are given in Fig. 2. The analysis indicates significant fluctuations of these indicators from year to year, taking into account changes in the national currency, which indicates, in particular, the state of regional budgets. Fluctuations, as seen in Fig. 2 in relation to the approximation dependence $y=2 \cdot 10^{6} \cdot e^{0.1425 x}$, are significant and reach up to $40 \%$. The trend line here and below is indicated in black.

Investment in waste management also fluctuates significantly from year to year. These fluctuations reach $50 \%$ or more. However, the positive thing about solving the problem of waste is that the rate of increase in annual costs on the item "waste management" has a general tendency to increase (Fig. 2) [4]. Effective spending of financial resources, the formation of realistic plans to address environmental problems in the face of budget deficits at all levels, required the creation of a tool for forecasting cash inflows. The result of forecasting for the purpose of convenient use by practitioners with different levels of training was presented in the form of analytical equations.

Using the method of quantitative and qualitative comparison to identify the correlation of data and isolation from random effects on the resulting function of non-random components. Since Ukraine has developed legislation on forecasting, in particular, the Law of Ukraine "On State Forecasting and Development of Economic and Social Development of Ukraine" (On State Forecasting and Elaboration of Ukraine's Economic and Social Development Programs: Law of Ukraine on March 23, 2000, No. 1602-III) and the recommendations of the National Bank of Ukraine on "coordination of methods and forms of forecasting macroeconomic and social development of Ukraine, and also monetary policy" [15], the formation of the mathematical apparatus must meet them. Then the results of the forecast can be used by state and regional structures responsible for budgeting waste management projects.

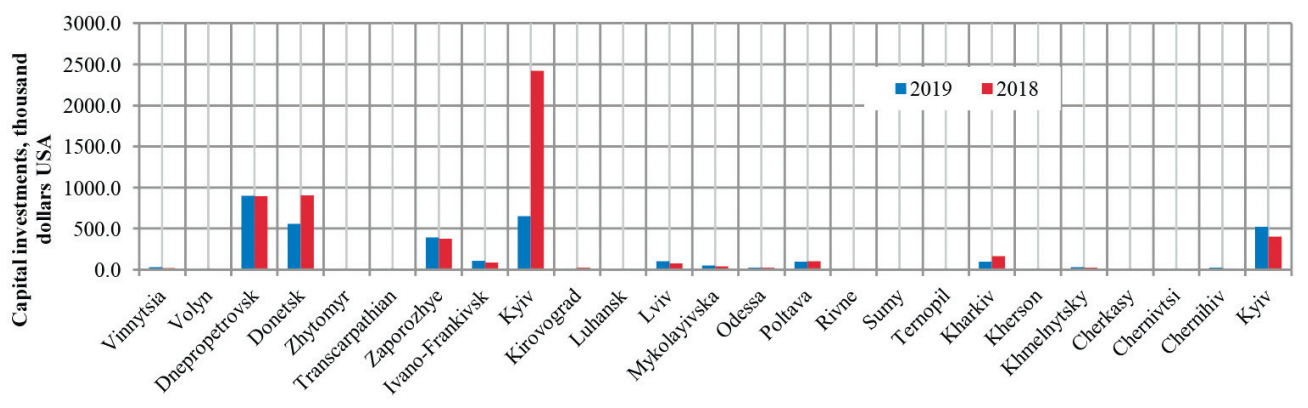

Fig. 1. Comparative analysis of capital investment in environmental protection by region, thousand US dollars 


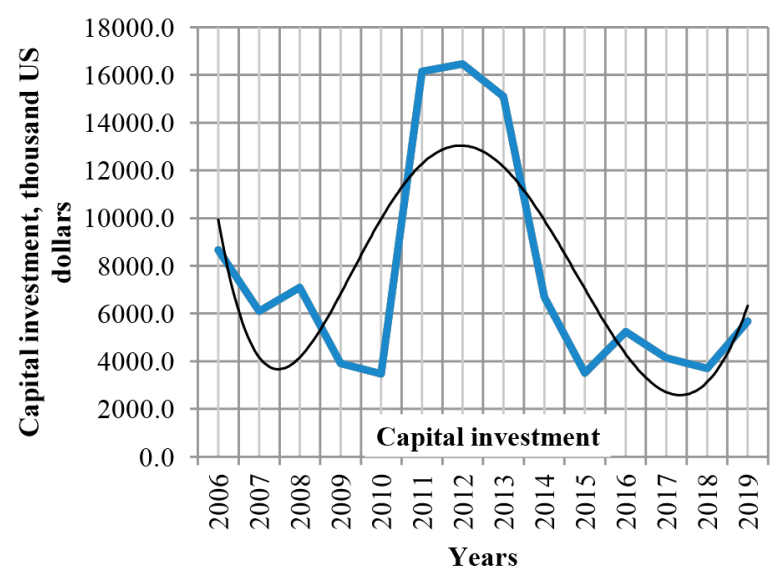

Fig. 2. Total capital investment in environmental protection from regional budgets, thousand US dollars

As it is known, the autoregressive model $\operatorname{AR}(p)$ can be analytically formalized as follows

$$
y_{\tau}=\sum_{i=1}^{p} a_{i} y_{\tau-i}+\varepsilon_{\tau},
$$

where $y$ is the forecast parameter; $\tau$ is the corresponding period of time; $i=1,2,3, \ldots ; p$ is the index of the time interval; $\varepsilon_{\tau}$ is the component that is defined as random and indicates the presence of so-called "white noise".

In cases related to the financing of environmental protection costs in general and according to the item "waste management", it is established that the value of $\varepsilon_{\tau}$ can be considered as

$$
\varepsilon_{\tau}=\varepsilon_{\tau}^{*}+\sum_{i=1}^{q} \varepsilon_{\tau-i}^{*}+\sum_{j=1}^{k} \varepsilon_{j}^{*},
$$

where is random variables that depend on the components of "white noise"; $q$ is the total number of such components; is components that correlate with the budget deficit, their number, and their index, respectively, is denoted as $j=1,2,3, \ldots, k$.

It is established that not all components $\varepsilon_{\tau}$ are random in the full sense of this definition. According to the results of the analysis, there is a correlation between the country's budget deficit, the threat of its sequestration and planning, and, moreover, the allocation of planned budgets for environmental protection, waste recycling, and others. But multidimensional correlation on many indicators is too complex, so the correlation on the integrated indicator was used (Fig. 3). The existence of such a correlation is explained by the fact that such expenditures are often considered non-priority and are subject to reduction in the absence of financial resources for other budget items. When $\varepsilon_{j}^{*}$ is really a random component, it is de-

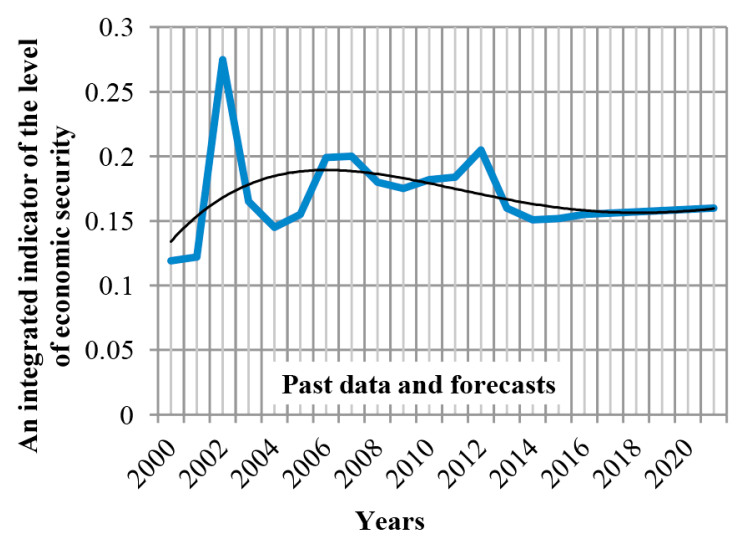

Fig. 3. Integrated indicator of the level of economic security termined by unknown parameters - the variance of $\sigma_{\varepsilon_{j}^{*}}^{2}$ and $p$ coefficients. That part of the $j^{\text {th }}$ components that clearly correlates with the budget forecast, its correction and the probability of sequestration is determined in accordance with the parameters, many of which are known, and the unknown part is adjusted in accordance with expert assessments of the impact of budgetary risks. That is, the presence of so-called "correlated noise" and its patterns are established. Data processing has also been found to generate certain types of "correlated noise". Such noise occurs, for example, when the input statistical information is provided not in the national currency, but in USA dollars because the exchange rate had significant abrupt changes, in particular, 1.49 times in the year 2014 to 2013, 1.84 times in 2015 to 2013. The presence of each type of "correlated noise" should be taken into account when making forecasts. According to the estimates of the impact of budgetary risks and the calculations, the ratio between the components $\varepsilon_{\tau}$ is determined

$$
\varepsilon_{\tau}^{*}+\sum_{i=1}^{q} \varepsilon_{\tau-i}^{*} \leq \sum_{j=1}^{k} \varepsilon_{j}^{*} .
$$

As it is known, the stationarity of ARMA models, which are a combination of AR and MA models, and, accordingly, $\operatorname{ARMA}(p, q)$ processes described by these models, is determined only by the AR segment. Therefore, in the transition to the formulation of the model, which should be used in forecasting indicators of future periods, we must take into account the peculiarities we have identified $\varepsilon_{j}^{*}$ and then ARMA model will be formed as follows

$$
y_{\tau}=\sum_{i=1}^{p} a_{i} y_{\tau-i}+\varepsilon_{\tau}^{*}+\sum_{i=1}^{q} b_{q} \varepsilon_{q-i}^{*}+\sum_{j=1}^{k} \varepsilon_{j}^{*},
$$

where $b_{q}$ is coefficients at the corresponding $\varepsilon_{q-i}^{*}$.

Implementation of ARMA models followed the wellknown Box-Jenkins algorithm: identification, parameter estimation, diagnostics, forecasting. The approach of forecasting was formalized, because its accuracy reached the accuracy of the conditional forecast of the use of such models, which is usually higher. For the calculations of $\varepsilon_{j}^{*}$ "Information on fiscal risks and their impact on the state budget in 2020" [16], "Methods for calculating the level of economic security of Ukraine" (Ministry of Economic Development and Trade of Ukraine (2013)). On approval of Methodical recommendations for calculating the level of economic security of Ukraine: Order of 29.10.2013, No. 1277 and forecast data of the Ministry of Finance (Ministry of Finance of Ukraine (2010). On approval of the Regulation on public debt risk management: Order of June 16, 2010, No. 46 were used. The data given in [17, 18] were also used. According to the calculations, a significant level of correlation was established between the integrated indicators of the level of economic security $(0.65)$, the fiscal load factor of the budget $(0.68)$, the capitalization ratio of budget expenditures $(0.76)$ and $\varepsilon_{j}^{*}$. Also, a significant level of reliability (0.84) was found between the budget deficit and expenditures on environmental protection and, in particular, expenditures on waste management. This dependence was formalized analytically

$$
S=-0.38 D^{2}+1.89 D,
$$

where $S$ is the ratio of capital expenditures according to the budget item "Environmental Protection" to gross domestic product; $D$ is the ratio of budget deficit to gross domestic product.

The research allowed establishing the practical reliability of the correlation between $\varepsilon_{j}^{*}$ and the integral indicator of the level of economic security of Ukraine, which was also studied in $[16,19]$. The calculations proved the reliability level of the dependence $\varepsilon_{j}^{*}$ and the integrated indicator of the level of eco- 
nomic security 0.92 . This allowed us to predict $\varepsilon_{i}^{*}$ with a high degree of reliability. Graphic representation of the calculated and statistical data and the forecast of the integrated indicator of the level of economic security are shown in Fig. $3[4,16]$.

To approximate and forecast the integrated indicator of the level of economic security, we selected the latest most stable period (Fig. 3) of 2014-2019. The polynomial equation for calculating the predicted values of the integrated indicator of the level of economic security has the form

$$
y=2 \cdot 10^{-16} x^{3}-0.0001 x^{2}+0.0023 x+0.1486 .
$$

This allowed making predictions and forming polynomial equations for use in analytical studies on environmental budgeting and relevant practical tasks, in particular, the planning of measures and projects for environmental protection (Fig. 4) [4].

The nature of changes in the integrated indicator since 2006 indicates significant fluctuations $-50 \%$ or more. This reduces the relevance of the forecast and confirms the thesis of the dual risks of environmental budgeting from regional and municipal budgets. The resulting polynomial equation (Fig. 5) [4] is

$$
y=-4791.5 x^{3}+148193 x^{2}-360704 x+3 \cdot 10^{6} .
$$

The results of analytical research using the methods of scientific abstraction and mathematical formalization. In contrast to significant fluctuations in capital investment in environmental protection from state and regional budgets, taking into account changes in the exchange rate of the national currency to the US dollar current spending on environmental protection by region is characterized by much smaller fluctuations from year to year (Fig. 5). This is due to the fact that differences in the types of current environmental expenditures in the regions are much smaller than in the country as a whole. For example, the current costs of maintaining the smooth operation of waste

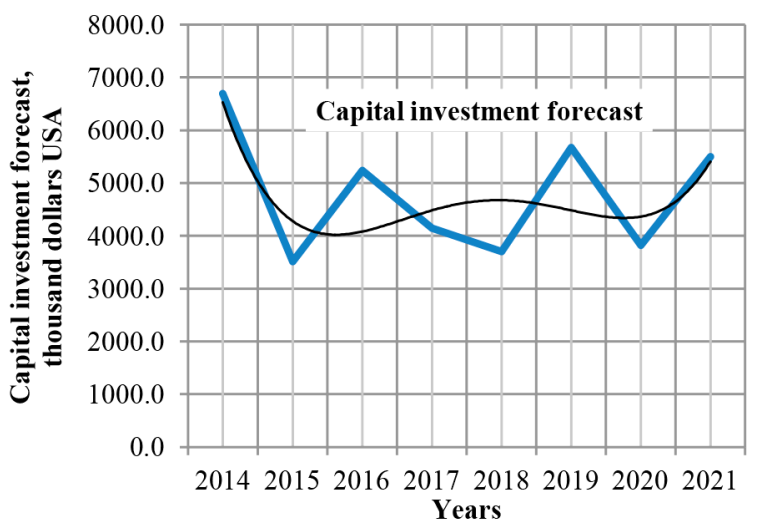

Fig. 4 Forecast of total capital investments for environmental protection by regions in actual prices; thousand US dollars

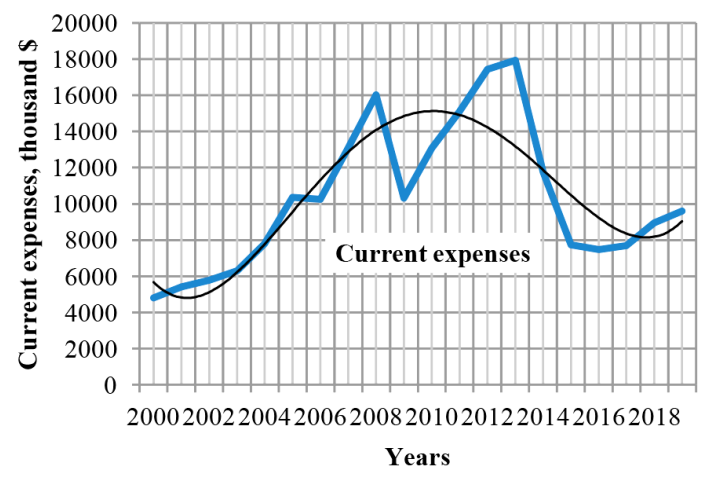

Fig. 5. Current costs of environmental protection in Ukraine in actual prices; thousand US dollars disposal sites are inevitable, their specific values fluctuate slightly and they are projected to increase with increasing waste both from year to year and with increasing total accumulated waste [20, 21].

Fig. 5 shows the results of analysis and forecasting of current environmental expenditures by region. According to the results of the analysis, this type of costs, taking into account changes in the exchange rate of the national currency to dollar US, is not characterized by significant fluctuations because current costs are necessary, which ensures a certain stability of their changes over the years.

The analytical equation that allows calculating the forecast data is

$$
\begin{gathered}
y=-25.8 x^{5}+1709.8 x^{4}-39421 x^{3}+434037 x^{2}-1041763 x+ \\
+401214 .
\end{gathered}
$$

The study on the stability and almost linear nature of the trend of current environmental expenditures by type of "waste management" from the state budget (Fig. 6) [4] is explained, unfortunately, not by positive changes in operational funding, in particular, maintenance of waste storage but the steady increase in waste. Data on the amount of waste sent for storage (Fig. 6) correlate with a high degree of reliability with current expenditures (Fig. 7) [4] on environmental protection by type of "waste management" $(0.87)$ for the period $2015-$ 2019.

The equation for forecasting the current costs of waste management is as follows

$$
\begin{gathered}
y=6537.3 x^{5}-94485 x^{4}+443532 x^{3}-620734 x^{2}+ \\
+760738 x-614925 .
\end{gathered}
$$

Forecasting the amount of waste to be disposed of in specially designated areas for the period 2010-2021 indicates the

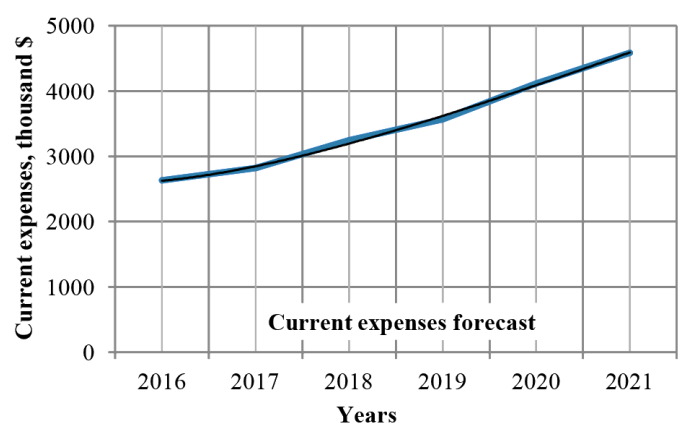

Fig. 6. Forecast of current expenditures from the state budget for environmental protection by type of "waste management" in actual prices; thousand US dollars)

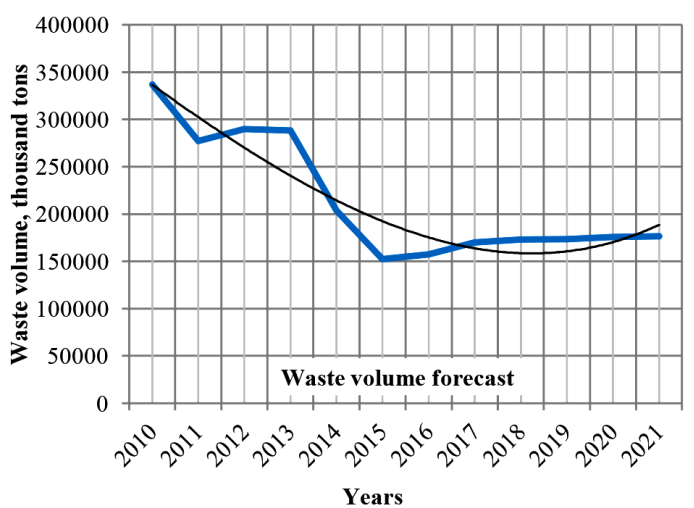

Fig. 7. Volumes of waste for disposal in specially designated places for the period 2010-2021 
interval of some stabilization of this indicator. Stabilization and slow, continuous growth of waste for disposal at storage sites begins in 2015 (Fig. 7). The equation for forecasting and approximating data on the amount of waste to be disposed of in specially designated areas has the following form

$$
y=121.5 x^{3}+256.78 x^{2}-35878 x+372161 .
$$

The situation with the growth of waste is significantly complicated by the fact that, firstly, there is a significant proportion of hazardous waste (so-called waste of I-III hazard classes) in the amount of waste delivered to its storage sites, and secondly, the practice often exists not to separate hazardous waste and waste of hazard class IV according to the place of its storage and accumulation.

This has a significant set of negative consequences, including the financing of environmental programs and the management of such waste.

The reason for the increase in the volume of accumulated waste of I-III hazard classes (up to $~ 1 \%$ of the annual volume) is the mismatch of the capacity of the existing technological equipment intended for utilization or incineration of hazardous waste. According to the State Statistics Service [4] for 2019, the volume of utilized hazardous waste is only $2 \%$ of the total amount of waste accumulated during operation in specially designated places and facilities. And the share of incinerated waste from this amount is even less - only $0.086 \%$. The volume of hazardous waste incineration has decreased by more than 1.5 times since 2010 , and the volume of utilization has decreased by $\sim 2.5$ times. Today, the number of existing facilities in Ukraine for waste management of all types, including household, is only 1023 units. From them: installations for waste incineration for the purpose of receiving energy 520 units; for waste incineration for the purpose of thermal processing of waste - 117 units; for utilization (processing) of waste -320 units, specialized installations for waste of I-III hazard classes only -58 units [4].

This indicates that the issue of hazardous waste management is extremely critical.

At the same time, the formation of a mixture of waste of hazard classes I-III and hazard class IV in the volume of accumulated waste limits the possibility of further use of relatively safe waste as a secondary raw material, the so-called "artificial minerals", and the disposal of hazardous component of this mixture must be preceded by its separation.

This requires significant additional budget funds for waste separation and significantly reduces the potential profits from the use of artificial minerals. The number of investors willing to finance programs to use it reduces accordingly.

Reducing the budgeting of hazardous waste management can lead to the accumulation of much more threatening environmental, political, image consequences for the regions and the country than the problem of accumulation of industrial waste of IV hazard class.

Therefore, the reduction of current expenditures on environmental protection by type of "waste management of I-III hazard classes" and capital investments under this budget item is limited, especially for regional budgets, where the influence of civil society on decision-making in this field is more sensitive for local authorities.

The current costs of environmental protection by type of "waste management" from 2000 to 2019 are presented in Fig. 8. Comparison of Fig. 5. and Fig. 8. indicates the similarity of the change in the indicators. This is due to the significant share of current costs of "waste management" in total costs.

To approximate the data on the current costs of waste management for the period of 2000-2019, an equation is obtained

$$
\begin{gathered}
y=29.437 x^{5}-1469.7 x^{4}+26068 x^{3}-170484 x^{2}+ \\
+547337 x-208097 .
\end{gathered}
$$

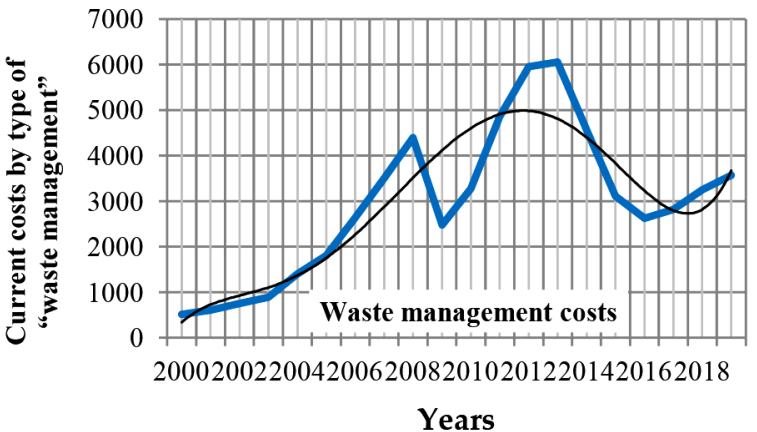

Fig. 8. Current expenditures for environmental protection by type of "waste management" for the period of 2000-2019 in actual prices; thousand US dollars

The conducted calculations and their analysis indicate that the volume of financing of environmental expenditures, capital investments, despite certain fluctuations, which are characteristic of the budget process in conditions of financial deficit, have a tendency to increase in the long run. It is also noteworthy that the current costs of waste management are less volatile and more stable. This, in our opinion, is largely due to the importance and growth of the problem of accumulation of industrial waste. A change in the situation can be achieved by strategic planning of introducing facilities meant to reduce the amount of waste that is directed for further storage.

The conducted research allows indicating that the formation of financial flows for environmental protection should be carried out according to a systematic approach. This is possible only with: system strategic planning in this sphere; ensuring transparency and control of all stages of the budget process - from the allocation of money, use of financial resources to obtaining the planned environmental and economic effects; synthesis of the budget process from forecasting to obtaining the final result; creation of a motivation basis for environmental protection by civil society.

Conclusions. To address the urgent issues of environmental protection in the face of a shortage of financial resources, it is proposed to introduce a strategic systemic approach both at the national level and at the regional level. An essential element of this approach is the availability of a mathematical apparatus for forecasting budget investments, current environmental costs and predicting the amount of industrial waste. Such a mathematical model was created and adapted to perform the tasks. Forecasting budget processes and financial flows for specific types of environmental measures, in particular, waste management provides an opportunity to predict the situation with the priority areas of environmental protection. Analytical dependences, presented in the form of polynomial equations on budgeting of ecological measures are formed. Trends and features of budget financing of ecological programs, in particular, industrial waste management, at the state and regional levels are revealed. The nonlinear nature of current costs and capital investments is indicated as well as the dependence of budgeting of environmental programs on the general level of economic security and the threat of lack of financial resources for other budget programs. It was found that, despite the chronic shortage of financial resources, there is a steady increase in current costs of waste management. This is not due to positive changes in the operational financing of maintenance of industrial waste storage sites, but the steady increase in their volume. According to the analysis of budget financing of environmental needs from regional budgets, it was found that they are characterized by more uneven changes than in the case of public funding as regional budgets have, in addition to the risks of national funding, additional risks characteristic of them. The analysis of the presented results allowed us to reveal the tendencies of the studied processes and 
to point out the ways of solving the problems with the financing of environmental protection in the conditions of the budget deficit. In the context of increasing risks of imbalances in regional environmental budgets in general, and the more critical and region-specific problem of waste accumulation with limited capacity to allocate additional areas for it, this approach provides an opportunity to assess the financial resources needed to address the most threatening problems and attract investors provided there are forecasts on the amount of funding, financial plans and guarantees to achieve results. Additional opportunities open up for both regional and state institutions to create a pool of assets if financial stability to solve environmental problems in the strategic perspective is provided. The conducted study indicates not only the ability to respond quickly to the growing environmental problems, but also the ability to finance and realize long-term goals. In a broader sense, it provides a tool for shaping the environmental sector as a single system.

\section{References.}

1. Order of the Cabinet of Ministers of Ukraine (2017). Strategy No. 820-p on November 8, 2017 (n.d.). Retrieved from https:// zakon.rada.gov.ua/laws/show/820-2017-\%D1\%80\#Text.

2. Piliaiev, I. (2019). The Value Dichotomy Curse of Ukraine's Modernization: to Break, or not to Be. Ukrainian Policymaker, 5, 68-76. https://doi.org/10.29202/up/5/8.

3. Artamonov, V. V., Mikhno, P. B., Vasylenko, M. H., \& Shelkovska, I. M. (2020). Basic procedures of planning the rational use of disturbed lands. Naukovyi Visnyk Natsionalnoho Hirnychoho Universytetu, (1), 158-164. https://doi.org/10.33271/ nvngu/2020-1/158.

4. State Statistics Service of Ukraine (2020). Retrieved from https://www.ukrstat.gov.ua/operativ/menu/menu_u/ns.htm. 5. Petruk, V., Stalder, F., \& Ishchenko, V. (2016). Management and treatment of solid waste. European experience. Vinnytsia: TOV "Nilan-LTD".

6. Melnyk, O.S., Koreneva, I. M., Zahorodnia, L.P., \& Danylchenko, I. H. (2017). Experience of European countries in solving environmental safety issues. Sumy: VVP "Mriia".

7. Voitsikhovska, A., Kravchenko, O., Melen-Zabramna, O., \& Pankevych, M. (2019). European best waste management practices. Lviv: "Manuskrypt".

8. Golyan, V., \& Shmarov, D. (2018). Integrated development of processing and food industries based on waste utilization: institutional prerequisites and investment support. Investytsiyi: praktyka ta dosvid, 13, 10-15.

9. Chugunov, I., \& Pasichniy, M. (2016). Financial policy in Ukraine in the terms of economic globalization. HERALD of Kyiv National University of Trade and Economics, 5, 5-18.

10. Ivanova, N. S. (2018). Forecasting of the economic security level of regions of the national economy. Derzhava ta rehiony. Seriya: Ekonomika ta pidpryyemnytstvo, 1, 33-38.

11. Bondarenko, E. (2017). Financial resources and financial flows: modern theory and practice management Investytsiyi: praktyka ta dosvid, 4, 25-28.

12. Sokiran, M. (2020). Space Critical Infrastructures as Part of Critical Infrastructures: Threats and Methods of Protection. Advanced Space Law, 5, 101-107. https://doi. org/10.29202/asl $/ 2020 / 5 / 11$.

13. Azzimonti, M., De Francisco, E., \& Quadrini, V. (2014). Financial globalization, inequality and the rising public debt. The American Economic Review, 104(8), 2267-2302. https:// doi.org/10.1257/aer.104.8.2267.

14. Ma, B. (2020). Value Shaping of Ecological Man: External Standard and Internal Idea. Future Human Image, 13, 57-65. https://doi.org/10.29202/fhi/13/6.

15. On methods and forms of forecasting macroeconomic indicators of economic and social development of Ukraine, as well as monetary policy (2019): Decision of the National Bank of Ukraine, Jan. 28, No. 1-pd (n.d.). Retrieved from https://zakon.rada.gov.ua/laws/show/vr001500-19\#Text.
16. Ministry of Finance of Ukraine (2019). Information on fiscal risks and their impact on the state budget in 2020. Official site. Reports (n.d.). Retrieved from https://mof.gov.ua/uk/zvity. 17. Pavlova, O. (2018). Politically-Technological Potential of Cultural Practices in Ukrainian Perspective. Ukrainian Policymaker, 2, 20-26. https://doi.org/10.29202/up/2/3.

18. Nguyen, N. T. (2020). Marine Culture of Northeast Vietnam: Approaching from the Theory of Culture Ecology. Future Human Image, 13, 66-75. https://doi.org/10.29202/ fhi $/ 13 / 7$.

19. Sokiran, M. (2019). Disaster Management, Resilience of System and Space Information Technologies. Advanced Space Law, 3, 120-130. https://doi.org/10.29202/asl/2019/3/10.

20. Rekova, N., Dolozina, I., Nitsenko, V., Zaitsev, Y., \& Zamlynskyi, V. (2018). Budgetary revenue structure at central level of public administration in the federal countries. Administratie si Management Public, 30, 37-50. https://doi. org/10.24818/amp/2018.30-03.

21. Andriushchenko, K., Datsii, O., Aleinikova, O., Abdulla, A. M., \& Ali, A.M. (2019). Improvement of the water resources management system at the territorial level. Problems and Perspectives in Management, 17, 421-437. https://doi. org/10.21511/ppm.17(3).2019.34.

\section{Фінансування екологічних програм поводження із промисловими відходами в умовах кризи}

\section{О. І. Дацій ${ }^{1}$ Н. В. Дацій ${ }^{2}$, о. М. Зборовськаз} Л. М. Івашова ${ }^{4}$, М. В. Черкашина, К. Л. Інграм ${ }^{6}$

1 - Міжрегіональна академія управління персоналом, м. Київ, Україна; e-mail: rvps1973@gmail.com

2 - Поліський національний університет, м. Житомир, Україна

3 - Запорізький національний університет, м. Запоріжжя, Україна

4 - Університет митної справи та фінансів, м. Дніпро, Україна

5 - Національна академія Національної гвардії України, м. Харків, Україна

6 - Вільнюський коледж, Університет прикладних наук, м. Вільнюс, Литовська Республіка

Мета. Провести аналіз фінансування з державного й регіональних бюджетів екологічних потреб у цілому та за статтею бюджету «поводження з відходами». Виявити кореляції даних і на їх основі побудувати математичний апарат прогнозу фінансування екологічних потреб за умов бюджетної кризи.

Методика. Результати дослідження отримані при застосуванні загальних і спеціальних методів пізнання. Для аналізу фінансування екологічних потреб у цілому та поводження з відходами зокрема використані методи порівняльного аналізу, контент-аналізу, логічного узагальнення. Метод кількісного та якісного порівняння використано для виявлення кореляції даних і виокремлення з випадкових впливів на результуючу функцію невипадкових компонент. Для побудови математичного апарату прогнозу фінансування екологічних потреб за умов бюджетної кризи використані методи наукового абстрагування й математичної формалізації.

Результати. Запропоновано запровадження стратегічного системного підходу для вирішення нагальних питань захисту довкілля й поводження із промисловими відходами в умовах дефіциту фінансових ресурсів як на рівні держави, так і на рівні регіонів. Для цього сформовано математичний апарат. Підвищення релевантності прогнозу досягнуто впровадженням оригінальної методики. Виявлені тенденції та особливості бюджетного фі- 
нансування екологічних програм на державному й регіональних рівнях. За хронічної нестачі фінансових ресурсів виявлена тенденція до стабільного зростання поточних витрат на поводження із відходами. Досліджені особливості фінансування екологічних потреб із регіональних бюджетів. Вказано, що на регіональні бюджети впливають окрім ризиків, властивих для загальнодержавного фінансування, ще власні набори ризиків.

Наукова новизна. Виявлена наявність корельованих компонент у білому шумі ARMA-моделей, що підвищило релевантність прогнозів фінансування екологічних програм в умовах кризи. Встановлена практична достовірність кореляції між деякими компонентами білого шуму та інтегральним показником рівня економічної безпеки. Виявлено, що для фінансування екологічних програм із регіональних бюджетів характерні більш нерівномірні зміни, ніж у випадку державного фінансування.

Практична значимість. Розроблені прогнози щодо обсягів промислових відходів для видалення у спеціально відведені місця та обсягів капітальних інвестицій і поточних витрат на поводження з відходами. Випробувані можливості математичної моделі для формування прогнозів майбутніх періодів. Для використання фахівцями прогнози для наступних років і апроксимації минулих періодів представлені у зручному аналітичному вигляді. Прогнозування бюджетних надходжень на екологічні потреби дозволяє планувати поетапне вирішення проблем охорони довкілля, долучати необхідні сторонні фінансові ресурси, збільшує можливості громадського контролю фінансових потоків і виходу на заплановані покажчики кожного з об'єктів інвестування. У більш широкому плані це надає інструмент для формування галузі захисту довкілля як єдиної системи.

Ключові слова: бюджетні витрати, промислові відходи, моделювання, прогнозування, управління відходами

\section{Финансирование экологических программ обращения с промышленными отходами в условиях кризиса}

\author{
А. И. Даций' , Н. В. Даций, О. М. Зборовская ${ }^{3}$, \\ Л. Н. Ивашова, М. В. Черкашина, К. Л. Инграм 6
}

1 - Межрегиональная академия управления персоналом, г. Киев, Украина; e-mail: rvps1973@gmail.com

2 - Полесский национальный университет, г. Житомир, Украина

3 - Запорожский национальный университет, г. Запорожье, Украина

4 - Университет таможенного дела и финансов, г. Днепр, Украина

5 - Национальная академия Национальной гвардии Украины, г. Харьков, Украина

6 - Вильнюсский колледж, Университет прикладных наук, г. Вильнюс, Литовская Республика

Цель. Провести анализ финансирования из государственного и региональных бюджетов экологических потребностей в целом и по статье «обращение с отходами». Выявить корреляции данных и на их основе построить математический аппарат прогноза финансирования экологических потребностей в условиях бюджетного кризиса.
Методика. Результаты исследования получены применением общих и специальных методов познания. Для анализа финансирования экологических потребностей в целом и на обращение с отходами в частности использованы методы сравнительного анализа, контент-анализа, логического обобщения. Методы количественного и качественного сравнения использованы для выявления корреляции данных и выделения из случайных воздействий на результирующую функцию неслучайных компонент. Для построения математического аппарата прогноза финансирования экологических нужд в условиях бюджетного кризиса использованы методы научного абстрагирования и математической формализации.

Результаты. Предложено введение стратегического системного подхода для решения неотложных вопросов защиты окружающей среды и обращения с промышленными отходами в условиях дефицита финансовых ресурсов как на уровне государства, так и на уровне регионов. Для этого сформирован математический аппарат. Повышение релевантности прогноза достигнуто внедрением оригинальной методики. Выявлены тенденции и особенности бюджетного финансирования экологических программ на государственном и региональных уровнях. При хроническом недостатке финансовых ресурсов выявлена тенденция к стабильному росту текущих расходов на обращение с отходами. Исследованы особенности финансирования экологических потребностей из региональных бюджетов. Указано, что на региональные бюджеты влияют кроме рисков, присущих общегосударственному финансированию, еще и собственные наборы рисков.

Научная новизна. Выявление коррелированных компонент в белом шуме ARMA-моделей повысило релевантность прогнозов финансирования экологических программ в условиях кризиса. Установлена практическая достоверность корреляции между некоторыми компонентами белого шума и интегральным показателем уровня экономической безопасности. Выявлено, что для финансирования экологических программ из региональных бюджетов характерны более неравномерные изменения, чем в случае государственного финансирования.

Практическая значимость. Разработаны прогнозы относительно объемов промышленных отходов для удаления в специально отведенные места и объемов капитальных инвестиций и текущих расходов на обращение с отходами. Испытаны возможности математической модели для формирования прогнозов будущих периодов. Для использования специалистами прогнозы для последующих лет и аппроксимации прошлых периодов представлены в удобном аналитическом виде. Прогнозирование бюджетных поступлений на экологические нужды позволяет планировать поэтапное решение проблем охраны окружающей среды, привлекать необходимые сторонние финансовые ресурсы, увеличивает возможности общественного контроля финансовых потоков и выхода на запланированные показатели каждого из объектов инвестирования. В более широком плане это предоставляет инструмент для формирования области защиты окружающей среды как единой системы.

Ключевые слова: бюджетные расходы, промышленные отходы, моделирование, прогнозирование, управление отходами

Recommended for publication by V. Ye. Dankevych, Doctor of Economic Sciences. The manuscript was submitted 14.08.20. 